\title{
Structure of stratlingite and effect of hydration methodology on microstructure
}

\section{Isabel Santacruz}

Ramón y Cajal Senior Researcher, Departamento de Química Inorgánica, Cristalografía y Mineralogía, Universidad de Málaga, Málaga, Spain Ángeles G De la Torre

Lecturer, Departamento de Química Inorgánica, Cristalografía y Mineralogía, Universidad de Málaga, Málaga, Spain

\section{Gema Álvarez-Pinazo}

PhD student, Departamento de Química Inorgánica, Cristalografía y Mineralogía, Universidad de Málaga, Málaga, Spain

\section{Aurelio Cabeza}

Lecturer, Departamento de Química Inorgánica, Cristalografía y Mineralogía, Universidad de Málaga, Málaga, Spain

\section{Ana Cuesta}

PhD student, Departamento de Química Inorgánica, Cristalografía y Mineralogía, Universidad de Málaga, Málaga, Spain

Jesús Sanz

Research Professor, Instituto de Ciencia de Materiales de Madrid (ICMM), Consejo Superior de Investigaciones Científicas (CSIC), Cantoblanco, Madrid, Spain

\section{Miguel A. G Aranda}

Professor, Departamento de Química Inorgánica, Cristalografía y Mineralogía, Universidad de Málaga, Málaga, Spain; CELLS-Alba Synchrotron, Barcelona, Spain

Stratlingite, $\mathrm{Ca}_{4} \mathrm{Al}_{2}(\mathrm{OH})_{12}\left[\mathrm{AISi}(\mathrm{OH})_{8}\right]_{2} \cdot 2 \mathrm{H}_{2} \mathrm{O}$, is an AFm phase which appears as a hydration product of aluminium-rich cements. These binders may be calcium aluminate cements, calcium sulfoaluminate cements and also belite calcium sulfo-aluminate (BCSA) cements. The structure of stratlingite is known from single-crystal studies of tiny minerals but their bulk formation, crystal structure and microstructure of powders is poorly understood. This paper reports on the synthesis of stratlingite and a complete structural and microstructural characterisation by synchrotron X-ray powder diffraction, nuclear magnetic resonance, scanning electron microscopy and thermal analyses. The structural and microstructural models have important implications for a correct quantitative phase analysis of stratlingite in cement pastes (for instance, in pastes of BCSA cements). The microstructure of stratlingite formed in cement pastes is highly dependent on the hydration conditions. In BCSA pastes, the (003) line position of stratlingite appears slightly shifted towards higher diffracting angles (lower inter-layered distance) after stopping hydration compared to that of a similar phase present in a paste analysed without stopping hydration. This is related to dehydration and disorder. This shift and peak broadening is even larger when the paste has suffered partial dehydration during curing (apart from stopping hydration). A microstructural study is presented.

\section{Introduction}

Ordinary Portland cement (OPC) production accounts for $6 \%$ of anthropogenic carbon dioxide emissions and for $4 \%$ of total global warming (Gartner, 2004; McCaffrey, 2002). The interest in eco-cements with new formulations arises from their potential to release up to $40 \%$ less carbon dioxide than OPC in their manufacture, depending on their composition. In the last few years, belite calcium sulfo-aluminate (BCSA) cements, also known as sulfobelite cements, have been developed as OPC substitutes (Cuberos et al., 2010; Gartner and Li, 2006; Morin et al., 2011). Although they have been proposed as a sustainable alternative to OPC, some technological challenges (Álvarez-Pinazo et al., 2013), such as relatively low mechanical strengths and durability, need to be improved. The understanding of the hydration processes (Klaus et al., 2013; Le Saoût et al., 2013; Winnefeld and Lothenbach, 2010) should lead to an improved design of the clinker composition (activation) and better performances after setting and hardening.
During the hydration process of calcium sulfoaluminate cements (CSA) and BCSA cements (Marchi and Costa, 2011; Sahu et al., 1991), there are three main occurrences: (a) dissolution of crystalline anhydrous phases, $(b)$ appearance of new phases (Aranda et al., 2012) such as crystalline stratlingite $\left(\mathrm{Ca}_{4} \mathrm{Al}_{2}(\mathrm{OH})_{12}\left[\mathrm{AlSi}(\mathrm{OH})_{8}\right]_{2} \cdot 2 \mathrm{H}_{2} \mathrm{O}\right)$ and amorphous gels; (c) consumption of free water. There is an increasing interest in the synthesis and advanced characterisation (Balonis and Glasser, 2009) of single phases that are involved in the hydration of cements, such as ye'elimite (Cuesta et al., 2013), belite (Cuesta et al., 2012, 2014), alite (De la Torre et al., 2002), katoite (Dilnesa et al., 2014), stratlingite (Kwan et al., 1995) and so on. The formation of these new crystalline phases in the cement pastes can be determined and quantified through X-ray powder diffraction (XRPD) jointly with the Rietveld methodology. Hence, the knowledge of the structure (and microstructure) of these individual phases makes possible the control of the hydration of the cement pastes and then the 
design of cement/mortars with improved properties/ performances.

In this context, full characterisation of stratlingite is important as this is an AFm-type phase which appears as a hydration product of aluminium-rich cements. These binders may be calcium aluminate cements, CSA and BCSA cements. Stratlingite is not formed by direct hydration of OPC, but it has been reported in the hydration of Portland binders with aluminium oxide-rich additions (for instance, fly ashes). Stratlingite is a mineral found as a metamorphosed limestone inclusion within the basaltic lava flow at Bellerberg, Mayern/Eifel (Fleischer and Jambor, 1977; Hentschel and Kuzel, 1976) and in a marly inclusion in a phonolitic lava (Campomorto, Italy, near Montalto di Castro) (Passaglia and Turconi, 1982).

A few methods have been reported for the preparation of stratlingite, including those outlined below.

(a) Reaction between calcium hydroxide and metakaolin in suspension (Taylor, 1997); depending on the composition and conditions, similar reactions of natural pozzolans can yield, besides calcium silicate hydrate gel, stratlingite or hydrogarnet. Stratlingite was first synthesised by this method.

(b) From a stoichiometric mixture of oxides (silicon dioxide, aluminium oxide and calcium oxide) with excess water at room temperature (RT) for 1.5-2 years (Kwan et al., 1995); this method produced poorly crystallised stratlingite. In an attempt to increase its crystallinity, the same authors treated hydrothermally the resulting suspension, $150^{\circ} \mathrm{C}$ overnight.

(c) Stoichiometric mixture of calcium aluminate cement, calcium oxide and metakaolinite for $3 \mathrm{~d}$ in the presence of alkali (Kwan et al., 1995).

(d) Slow hydration of calcium aluminium silicate glasses in saturated solutions of calcium hydroxide at $20^{\circ} \mathrm{C}$ for $120 \mathrm{~d}$ (Kuzel, 1976).

(e) Stoichiometric mixture of calcium oxide, $\mathrm{Na}_{2} \mathrm{Si}_{2} \mathrm{O}_{5} \cdot 2 \mathrm{H}_{2} \mathrm{O}$ and sodium aluminate $\left(\mathrm{NaAlO}_{2}\right)$ in water, which was stirred for 4 weeks at RT prior to filtration (Balonis and Glasser, 2009; Matschei et al., 2007a). The best result seems to be obtained by this last route. Some properties of these stratlingite powders (cell dimensions, space group, density, etc.) are described elsewhere (Balonis and Glasser, 2009).

Stratlingite, like any AFm-type phase, has a layer structure with the following general formula $\left[\mathrm{Ca}_{2} \mathrm{Al}(\mathrm{OH})_{6}\right] \mathrm{X} \cdot \mathrm{yH}_{2} \mathrm{O}$. For stratlingite, $\mathrm{X}$ is the $\left[\mathrm{SiAlO}_{2}(\mathrm{OH})_{4}\right]^{-}$anion which forms a double tetrahedral layer containing $\sim 50 \%$ vacancies. Moreover, iron-bearing stratlingite may also be formed by partial substitution of aluminium in the octahedral layer (Wang, 2010). Rinaldi et al. (1990) described the crystal structure of stratlingite (mineral fragments from Mayern and Montalto di Castro) as: (a) a principal octahedral or brucite-type layer,
$\left[\mathrm{Ca}_{2} \mathrm{Al}(\mathrm{OH})_{6} \cdot 2 \mathrm{H}_{2} \mathrm{O}\right]^{+}$with a full occupancy, and $(b)$ a double tetrahedral layer, $\left[(\mathrm{T}, \square)_{4}(\mathrm{OH}, \mathrm{O})_{8} \cdot 0 \cdot 25 \mathrm{H}_{2} \mathrm{O}\right]^{-}$, with $45 \%$ of vacancies. The octahedral layer has an overall positive charge, and the double tetrahedral layer negative. They proposed a silicon/aluminium atomic ratio of 1 , where the siliconaluminium order was not detected. The reduced chemical formula derived from the structure refinement was $\mathrm{Ca}_{2} \mathrm{Al}(\mathrm{Al}$, $\mathrm{Si})_{2 \cdot 28} \mathrm{O}_{2}(\mathrm{OH})_{12} \cdot 2 \cdot 25 \mathrm{H}_{2} \mathrm{O}$, where the unbalanced charge should be compensated with a silicon/aluminium atomic ratio slightly different from 1 , or the possible vacancy of some anionic sites. The symmetry of stratlingite is $\mathrm{R} 3 \mathrm{~m}$. The structure analysis (Rinaldi et al., 1990) indicates that the octahedral layer shows an ordered scheme where each aluminium-octahedron is linked to six edge-sharing $\mathrm{Ca}^{\mathrm{VII}}$ polyhedra (two out of three positions are then occupied by the seven coordinated Ca-type cation). When present, sodium ions could substitute for calcium ions in this layer. The structure also contains hydration water. Most of the water is located in the aluminium octahedral layer (in the seventh vertex, Ow2) projecting towards the centre of the six-membered rings of the double tetrahedral layers. These water molecules form hydrogen bonds between the neighbouring octahedral and tetrahedral layers and tend to hold the modules together. One additional water molecule site (Ow1, with partial occupancy) was located at the centre of the six rings of the double tetrahedral layers. In addition, the double tetrahedral layers show an unusual (energetically unstable) T-O-T angle (where $\mathrm{T}$ means tetrahedral) of $180^{\circ}$. It may be favoured by the large proportion of vacancies (Rinaldi et al., 1990) or by long-range averaging (although locally bent).

These conclusions were corroborated by Kwan et al. (1995) through the characterisation of synthesised stratlingite powder (from oxides) by some techniques, such as nuclear magnetic resonance (NMR). These authors confirmed that the aluminium atoms are both tetrahedral and octahedral, and the silicon atoms exist predominantly as $\mathrm{Q}_{2}, \mathrm{Q}_{2}(1 \mathrm{Al})$ and $\mathrm{Q}_{2}(2 \mathrm{Al})$ species. The presence of alkali affects the structure of stratlingite in subtle ways, significantly reducing the $\mathrm{Al}^{\mathrm{IV}} / \mathrm{Al}^{\mathrm{VI}}$ ratio. Similarly to Rinaldi et al. (1990), Kwan et al. (1995) confirmed that the aluminium substitution in the six-membered rings present in stratlingite (synthesised from oxides) seem to be random and equally divided among $\mathrm{Q}_{2}, \mathrm{Q}_{2}(1 \mathrm{Al})$ and $\mathrm{Q}_{2}(2 \mathrm{Al})$ sites, all bands having approximately the same area. However, this sample also exhibits evidence for a possible $\mathrm{Q}_{3}(2 \mathrm{Al})$ component which may have $\mathrm{OH}^{-}$ions associated with it. This suggests that the $45 \%$ vacancies of the six-membered rings in the double tetrahedral layers are breaking up the network structure. This reduces the network to a series of complex silicate ring structures which occasionally bond to each other. A $\mathrm{Q}_{3}$ silicate anion occurs when two of the rings share a silicon atom by cross linking. The data suggested that the relative ratio of $\mathrm{Q}_{2} / \mathrm{Q}_{3}$ should be much higher than 1 .

Additionally, it is important to understand the performances for specific applications, such as nuclear waste containments 
and long-lasting infrastructure developments. In this sense, the response under high pressures is important. Moon et al. (2011) studied the effects of pressure on the structure of synthesised stratlingite (Matschei et al., 2007b) through synchrotron X-ray powder diffraction (SXRPD). The sample showed a sudden volume contraction of around $1.5 \mathrm{GPa}$, where the estimated volume was $1.035 \mathrm{~nm}^{3}$, and transformed irreversibly to an amorphous phase at $3.4 \mathrm{GPa}$. Per formula unit of stratlingite, the interlayer/tetrahedral unit, $\left[\mathrm{AlSi}(\mathrm{OH})_{8} \cdot \mathrm{H}_{2} \mathrm{O}\right]^{-}$, contains only one molecule of water. Considering the hypothesis of pressure-induced dehydration, the stiffness of the crystal should increase once water molecules move out from the calcium aluminosilicate framework. This phenomenon was confirmed by these authors where an increase in stiffness was observed for pressures greater than $1.5 \mathrm{GPa}$. The slight rearrangements of structural elements, even if several weak interlayer water bonds are broken, are not enough to destroy the crystal framework of the sample, which transforms from stratlingite to 'metastratlingite'.

The present work has two main objectives. First to synthesise stratlingite, perform a complete structural and microstructural characterisation including SXRPD, NMR, scanning electron microscopy (SEM) and thermal analyses; second to study the implications of the revised structure and microstructure on the quantitative phase analysis of BCSA eco-cement pastes prepared under different hydration conditions at the same aging time.

\section{Materials and methods}

Materials

\section{Preparation of stratlingite}

Stratlingite was synthesised following a similar methodology to that reported by Balonis and Glasser (2009) and Matschei et al. (2007b). Stoichiometric mixtures of $\mathrm{Na}_{2} \mathrm{SiO}_{3} \cdot 5 \mathrm{H}_{2} \mathrm{O}$ (Aldrich), $\mathrm{NaAlO}_{2}$ (sodium aluminate) (Sigma-Aldrich) and $\mathrm{CaO}$ (calcium oxide) (from $\mathrm{CaCO}_{3}$ (calcite), Alfa Aesar) were added into double-boiled distilled water at $20^{\circ} \mathrm{C}$. The water/ solid ratio was 10 , and the raw mixture was prepared with the amounts of starting materials needed for obtaining $5 \mathrm{~g}$ of stratlingite. The suspension was stirred for 8 weeks at $20^{\circ} \mathrm{C}$. Then, the sample was pressure-filtered in a dry chamber with nitrogen, and washed by flushing with double-boiled distilled water (twice) to eliminate any remaining sodium (Matschei et al., 2007b), and flushed with acetone (once) for drying. Finally, the resulting powder was dried for $2 \mathrm{~d}$ in a stove at $30^{\circ} \mathrm{C}$.

\section{Preparation of belite calcium sulfoaluminate cement pastes}

Laboratory BCSA clinker (Álvarez-Pinazo et al., 2012) and pastes (Álvarez-Pinazo et al., 2013) were prepared as previously reported. The as-prepared BCSA paste was gathered in two groups and treated as follows: $(a)$ transferred into a methacrylate sample holder covered with plastic wrap and statically stored in a humidity chamber at $99 \%$ relative humidity $(\mathrm{RH}) ;(b)$ cast in a hermetically closed polytetrafluoroethylene (PTFE) cylinder shape mould rotated at $15 \mathrm{r} / \mathrm{min}$ for $24 \mathrm{~h}$. After that time, this sample was kept in deionised water. Both groups of samples were kept at $20 \pm 1^{\circ} \mathrm{C}$ for a total of $7 \mathrm{~d}$.

Prior to laboratory X-ray powder diffraction (LXRPD) characterisation, pastes were ground to a fine powder in an agate mortar. The hydration of the pastes was stopped prior to LXRPD characterisation. The experimental procedure to stop the hydration consists of filtration with acetone and ether, as is reported by García-Maté et al. (2013). Furthermore, the ground powder, prepared by $(b)$ procedure, was characterised with and without stopping hydration, named hereafter (b) and (b') methodologies, respectively.

\section{Analytical techniques}

\section{Scanning electron microscopy}

The as-prepared powder was characterised through SEM (Jeol JSM-6490LV). Semi-quantitative values of silicon/aluminium, silicon/calcium and aluminium/calcium weight ratios were obtained by SEM combined with energy dispersive spectroscopy (EDS) by analysing 90 different particles. The sample had been previously gold sputtered.

\section{Synchrotron X-ray powder diffraction}

The SXRPD pattern for stratlingite was recorded in DebyeScherrer (transmission) mode using the X-ray powder diffraction station of ALBA, the Spanish Synchrotron Radiation Facility (Barcelona, Spain) (Fauth et al., 2013). The wavelength, 0.6202(2) $\AA$, was selected with a double-crystal Si (111) monochromator and determined from a Si640d NIST standard $(a=0.543123 \mathrm{~nm})$ pattern. The diffractometer is equipped with a multi-crystal analyser detector system especially suited for high-resolution experiments. The capillary was rotated during data collection to improve diffracting particle statistics. The data acquisition time was $\sim 6 \mathrm{~h}$ to attain very good signalto-noise ratio over the angular range $1-45^{\circ}(2 \theta)$. The temperature inside the experimental hutch was $26 \pm 1^{\circ} \mathrm{C}$.

The SXRPD pattern of stratlingite was analysed by the Rietveld method as implemented in the GSAS software package (Larson and Von Dreele, 2000). The refined overall parameters were cell parameters, zero-shift error, peak shape parameters and phase scales. Peak shapes were fitted by using the pseudo-Voigt function (Thompson et al., 1987)

\section{Laboratory X-ray powder diffraction}

LXRPD studies were performed in reflection mode $(\theta / 2 \theta)$ on cured BCSA cement pastes. Patterns were recorded on an X'Pert MPD Pro diffractometer (PANalytical) using strictly monochromatic CuKal radiation $(\lambda=0 \cdot 154059 \mathrm{~nm})[\mathrm{Ge}(111)$ primary monochromator]. The X-ray tube worked at $45 \mathrm{kV}$ and $40 \mathrm{~mA}$. The optics configuration was a fixed divergence 
slit $\left(1 / 2^{\circ}\right)$, a fixed incident anti-scatter slit $\left(1^{\circ}\right)$, a fixed diffracted anti-scatter slit $\left(1 / 2^{\circ}\right)$ and X'Celerator RTMS (realtime multiple strip) detector, working in scanning mode with maximum active length. Data were collected from $5^{\circ}$ to $70^{\circ}$ (20) during $\sim 2 \mathrm{~h}$. The samples were rotated during data collection at $16 \mathrm{r} / \mathrm{min}$ in order to enhance particle statistics.

\section{Thermal analysis}

Differential thermal (DTA) and thermogravimetric (TGA) analyses were performed on the stratlingite powder in a SDTQ600 analyser from TA instruments (New Castle, DE). The temperature was varied from RT to $1000^{\circ} \mathrm{C}$ at a heating rate of $5^{\circ} \mathrm{C} / \mathrm{min}$. Measurements were carried out in an open platinum crucible under nitrogen flow. The weighed loss from RT to $\sim 550^{\circ} \mathrm{C}$ was assumed to be water (free and chemically bound water) and that from $\sim 550^{\circ} \mathrm{C}$ to $1000^{\circ} \mathrm{C}$ was considered as carbon dioxide.

\section{Nuclear magnetic resonance experiments}

$1 \mathrm{H}, 29 \mathrm{Si}$ and 27Al magic-angle spinning (MAS), 29Si $\{1 \mathrm{H}\}$ and $27 \mathrm{Al}\{1 \mathrm{H}\}$ cross-polarisation (CP-MAS) experiments were conducted on a Bruker Avance-400 NMR spectrometer with a $9.39 \mathrm{~T}$ widebore superconducting magnet. MAS-NMR and CP-MAS spectra were recorded at RT with $4 \mathrm{~mm}$ zirconia (PSZ) rotors at a spinning rate of $10 \mathrm{kHz}$. 29Si MAS NMR spectra were recorded at $79.49 \mathrm{MHz}$. Spectra were obtained after irradiating the samples with a $\pi / 2(6 \mu \mathrm{s})$ pulse, relaxation delay (D1) of $30 \mathrm{~s}$ and 800 scans. Kaolin $(\delta=-91.5 \mathrm{ppm})$ and tetramethylsilane (TMS) $(\delta=0)$ were used as external standards. 27Al MAS-NMR were recorded at $104.26 \mathrm{MHz}$, with a pulse width of $2 \mu \mathrm{s}$, relaxation delay (D1) of $10 \mathrm{~s}$ and 64 scans. Chemical shifts for aluminium components were referred to an aqueous solution of $\mathrm{AlCl}_{3} \cdot 6 \mathrm{H}_{2} \mathrm{O}(\delta=0)(1 \mathrm{M}) .1 \mathrm{H}$ MAS-NMR spectra were recorded at $400 \cdot 13 \mathrm{MHz}$. These spectra were obtained with a $\pi / 2(5 \mu \mathrm{s})$ pulse, relaxation delay (D1) of $5 \mathrm{~s}$ and 240 scans. 29Si CP MAS-NMR data were recorded on selected samples at short contact time (P15) of $1 \mathrm{~ms}$ and 1200 scans. In cross-polarisation experiments, 29Si spin gathers higher polarisation from the proton-spin reservoir, favouring detection of silicon nuclei that are submitted to dipolar interactions with protons. 27Al CP MAS-NMR data were recorded at contact time (P 15) of $1 \mathrm{~ms}$ and 400 scans. In these experiments detection of $\mathrm{Al}$ cations located near protons will be again favoured.

\section{Results and discussion}

Stratlingite phase sample

After several attempts to prepare crystalline stratlingite, the synthesis described in the experimental section gave the best sample. This paper considers the 'best' sample containing the highest amount of stratlingite with relatively sharp powder diffraction peaks. In fact, the Rietveld quantitative phase analysis (RQPA) of the SXRPD pattern gave $85 \cdot 2(1) \mathrm{wt} \%$ of stratlingite, $9 \cdot 5(1) \mathrm{wt} \%$ of calcite- $\mathrm{CaCO}_{3}$ (ICSD-80869), 4·2(2) $\mathrm{wt} \%$ of vaterite- $\mathrm{CaCO}_{3}$ (ICSD-15879), $0 \cdot 7(1) \mathrm{wt} \%$ of monocarbo-AFm (ICSD-59327), and 0.4(1) wt $\%$ of plazolite (ICSD-31250). Furthermore, DT-TGA experiments showed a weight loss of $\sim 30 \mathrm{wt} \%$ between RT and $\sim 550^{\circ} \mathrm{C}$. This mass loss agrees quite well with the expected mass loss for eight molecules of water of the stratlingite content, in agreement with the literature (Kwan et al., 1995; Rinaldi et al., 1990).

\section{Stratlingite structure and microstructure}

Figure 1 shows a representative SEM micrograph of the asprepared stratlingite powder. It is formed by laminar particles with an average size of $1-2 \mu \mathrm{m}$ (width) and less than $0 \cdot 1 \mu \mathrm{m}$ (thickness). Table 1 shows the obtained results by SEM-EDS, and those shown in the literature (Rinaldi et al., 1990) for the sake of comparison. These results match pretty well, although the sample studied here is slightly richer in silicon and poorer in aluminium.

The crystal structure of the bulk powder of stratlingite was studied using as starting model the structural description reported by Rinaldi et al. (ICSD-69413) from a mineral (Rinaldi et al., 1990). It must be highlighted that the anisotropic peak broadening of this sample was severe, in agreement

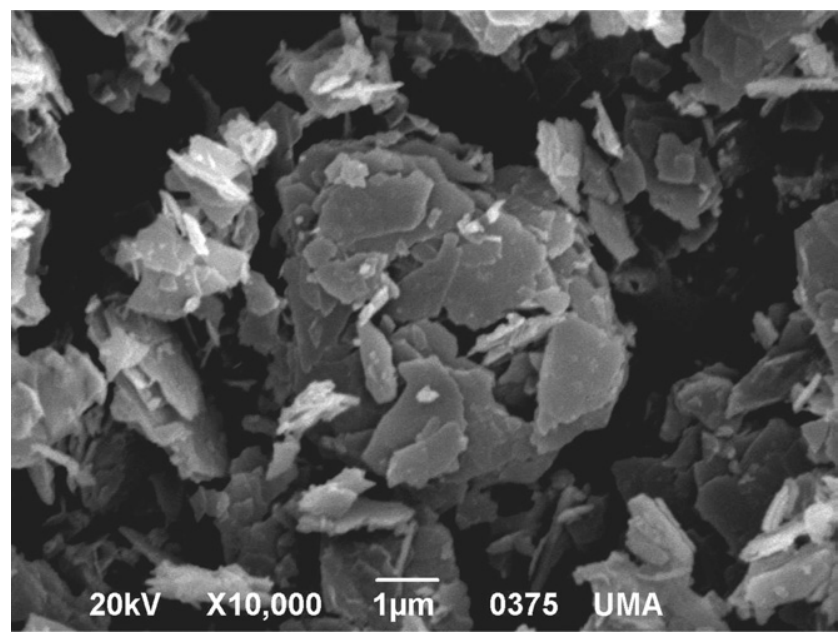

Figure 1. Scanning electron micrograph of laboratory-prepared stratlingite displaying the layered microstructure

\begin{tabular}{lclc}
\hline & $\begin{array}{c}\text { Silicon/ } \\
\text { aluminium }\end{array}$ & $\begin{array}{c}\text { Silicon/ } \\
\text { calcium }\end{array}$ & $\begin{array}{c}\text { Aluminium/ } \\
\text { calcium }\end{array}$ \\
\hline $\begin{array}{l}\text { This study } \\
\text { Literature }\end{array}$ & $0.7(1)$ & $0.43(6)$ & $0.60(8)$ \\
& 0.58 & 0.41 & 0.70
\end{tabular}

(Rinaldi et al. 1990)

Table 1. Silicon/aluminium, silicon/calcium and aluminium/calcium weight ratios of the laboratory-synthesised stratlingite obtained by SEM-EDS and those reported in literature 
with the SEM study, and this has to be properly modelled. For the stratlingite peak shape, the isotropic Gaussian contribution, GW, was negligible and a Lorentzian function was used (Thompson et al., 1987). The final refined parameters were $\mathrm{LX}=0 \cdot 008(1)^{\circ}, \mathrm{LY}=0 \cdot 26(1)^{\circ}$ and $\mathrm{PTEC}=0 \cdot 071(1)^{\circ}$. The last parameter defines the anisotropic broadening along the $c$-axis. The anisotropic peak broadening was very strong and it can be visualised by the full width at the half maximum (FWHM) values. The (003) reflection at $2 \cdot 80^{\circ}$ (20) (or $1.2579 \mathrm{~nm}$ ) was quite broad with a FWHM value of $0.089^{\circ}$

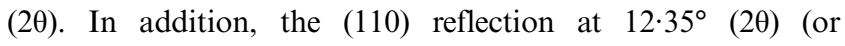
$0.2877 \mathrm{~nm}$ ) was very sharp with a FWHM value of $0.037^{\circ}$ (20). Figure 2 shows the Rietveld plot of the SXRPD pattern with the optimised structure and microstructure models. The refined unit cell parameters were $a=b=0 \cdot 57535(2) \mathrm{nm}$ and $c=3.7731(3) \mathrm{nm}$. The structural refinement includes atomic positions and isotropic atomic displacement parameters (ADPs). However, the high degree of disorder and the lack of diffraction peaks over $35^{\circ}(2 \theta ; \lambda=0.062 \mathrm{~nm})$ yields physically unrealistic iso-ADPs if no constraints were used. Therefore, all oxygen-OH, oxygen-oxo and oxygen-water were constrained to have the same value. The final Rietveld disagreement factors were $R_{\mathrm{WP}}=6 \cdot 3 \%$ and $R_{\mathrm{F}}=7 \cdot 5 \%$. Table 2 shows the final refined values of the positional parameters and ADP factors.

Figure 3(a) depicts the crystal structure of stratlingite where selected atoms are labelled. Octahedral and double tetrahedral layers are shown in detail in Figures 3(b) and 3(c),

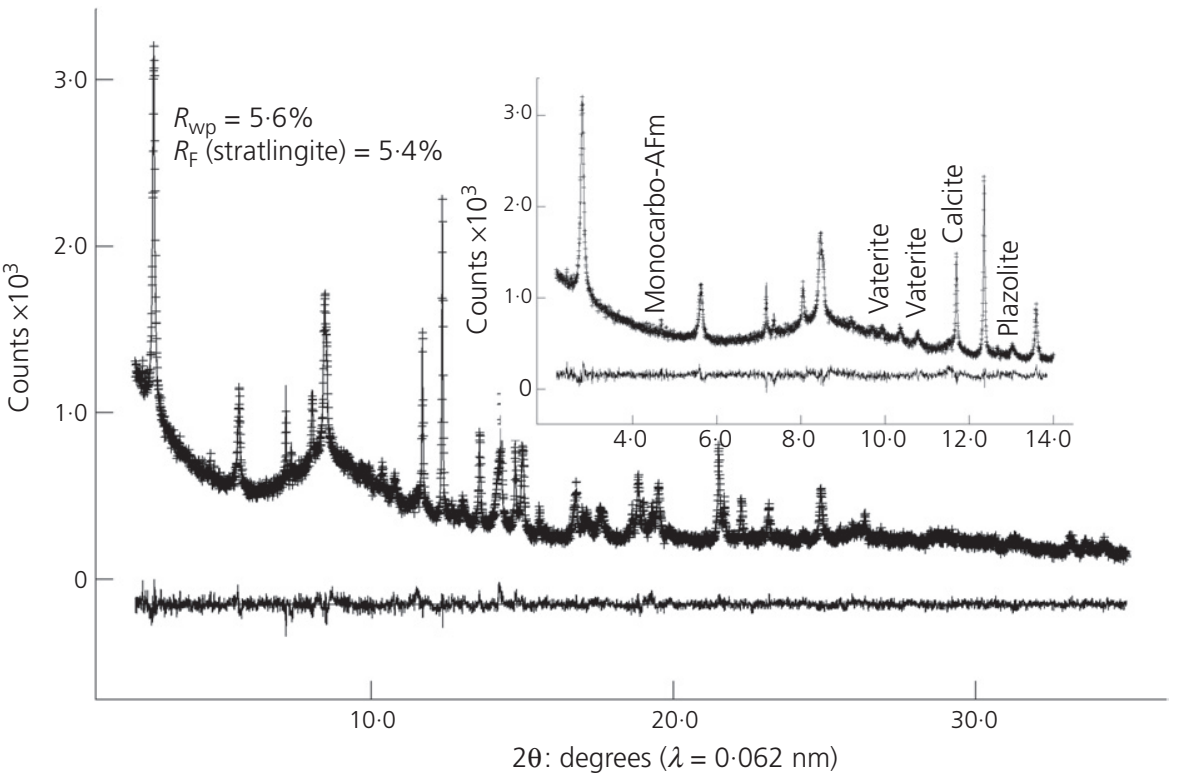

Figure 2. SXRPD Rietveld plot for laboratory synthesised

stratlingite. Inset shows an enlarged angular range where main

peaks due to minor phases are labelled

\begin{tabular}{lcccccc}
\hline Atom & Type & o.f. & $x$ & $y$ & $z$ & Isotropic-ADP/nm $^{2}$ \\
\hline Aluminium & 3a & 1.0 & $0.0000(-)$ & $0.0000(-)$ & $0.0000(-)$ & $0.015(3)$ \\
Calcium & 6c & 1.0 & $0.3333(-)$ & $0.6667(-)$ & $0.0146(1)$ & $0.002(2)$ \\
OH1 & $18 \mathrm{~h}$ & 1.0 & $0.8311(6)$ & $0.1689(6)$ & $0.1046(2)$ & $0.039(2)$ \\
OH2 & 36i & 0.5 & $0.737(1)$ & $0.043(1)$ & $0.0273(2)$ & $0.039(2)$ \\
O1 & 6c & 1.0 & $0.6667(-)$ & $0.3333(-)$ & $0.1678(4)$ & $0.039(2)$ \\
SiT1 & 6c & 0.5 & $0.0000(-)$ & $0.0000(-)$ & $0.1212(4)$ & $0.025(4)$ \\
SiT2 & 6c & 0.5 & $0.6667(-)$ & $0.3333(-)$ & $0.1241(4)$ & $0.031(4)$ \\
Ow1 & 3b & 0.25 & $0.3333(-)$ & $0.6667(-)$ & $0.1667(-)$ & $0.039(2)$ \\
Ow2 & 6c & 1.0 & $0.3333(-)$ & $0.6667(-)$ & $0.0873(3)$ & $0.039(2)$
\end{tabular}

Table 2. Final position, occupation factor (o.f.) and ADPs from stratlingite crystal structure refinement 


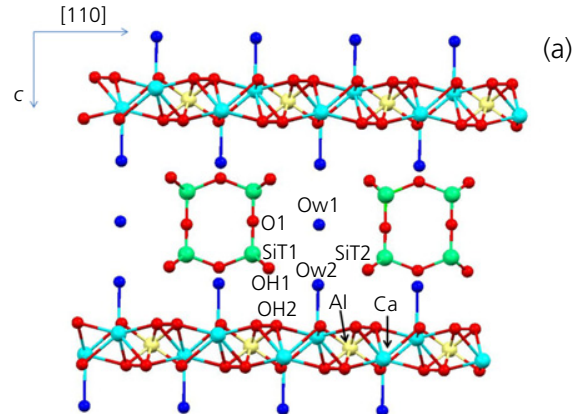

(b)
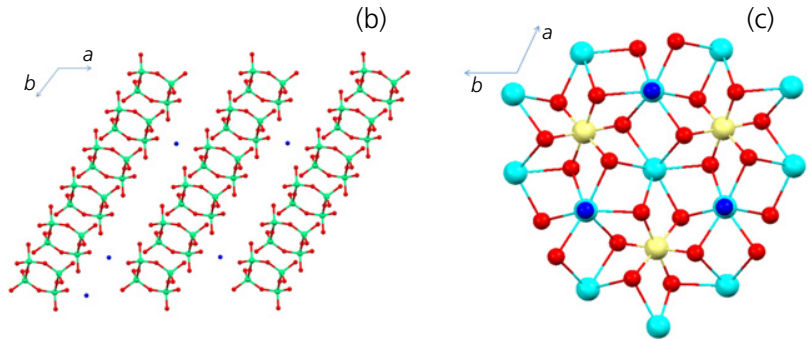

Figure 3. (a) Layered crystal structure of stratlingite. (b) Enlarged view of the double tetrahedral layer. (c) Enlarged view of the octahedral layer

respectively, along $a$ - and $b$-axes. The octahedral layer has the $\left[\mathrm{Ca}_{2} \mathrm{Al}(\mathrm{OH})_{6}\left(\mathrm{H}_{2} \mathrm{O}\right)_{2}\right]^{+}$composition and the tetrahedral double-layer can be described as $\left[\mathrm{Si}_{1 \cdot 24} \mathrm{Al}_{0 \cdot 76} \square_{2} \mathrm{O}_{2}(\mathrm{OH})_{4 \cdot 242}\right.$ $\left.\left(\mathrm{H}_{2} \mathrm{O}\right)_{0.25}\right]^{-}$where silicon/aluminium ratio is consistent with SEM results given in Table 1. Consequently, the tetrahedral layer may contain $2 \mathrm{~mol}$ of oxygen-oxo and $4.242 \mathrm{~mol}$ of hydroxyl groups $(\mathrm{OH})$, for neutral charge of the compound, which some of them will be either $\mu$-oxo or $\mu$-hydroxy bridges, and the rest will be end-members.

The CIF file, with the crystal structure data, is also deposited. It has to be noted that it is not possible to deduce the silicon/ aluminium occupancy by X-ray diffraction because they have (almost) the same number of electrons. The occupancy factors (o.f.) for oxygen-OH (OH1 and $\mathrm{OH} 2)$ and oxygen-oxo (O1) cannot be deduced because these sites can be partially occupied by both types of species.

${ }^{29} \mathrm{Si},{ }^{27} \mathrm{Al}$ and ${ }^{1} \mathrm{H}$ NMR (MAS and CP-MAS) spectra for asprepared stratlingite powders are shown in Figures 4(a), 4(b) and $4(\mathrm{c})$, respectively. The band located close to $\sim-86 \mathrm{ppm}$ in all ${ }^{29} \mathrm{Si}$ spectra (Figure 4(a)) could be ascribed to $\mathrm{Q}_{3}(2 \mathrm{Al})$ or $\mathrm{Q}_{2}(1 \mathrm{Al})$. However, according to the chemical formula and data from the literature (Kwan et al., 1995) should be better ascribed to $\mathrm{Q}_{2}$, because of the existence of vacancies in the double tetrahedral silicate ring structure. The double tetrahedral layer, $\left[\mathrm{Si}_{2} \mathrm{Al}_{2} \mathrm{O}_{4}(\mathrm{OH})_{8}\right]^{2-}$, has to show a large amount of vacancies to give the formula $\left[\mathrm{Si}_{1 \cdot 24} \mathrm{Al}_{0 \cdot 76} \square_{2} \mathrm{O}_{2}(\mathrm{OH})_{4 \cdot 242}\right.$ $\left.\left(\mathrm{H}_{2} \mathrm{O}\right)_{0 \cdot 25}\right]^{-}$, which also explains the low tetrahedral condensation observed in ${ }^{29} \mathrm{Si}$ spectra. ${ }^{29} \mathrm{Si}$ MAS NMR also shows

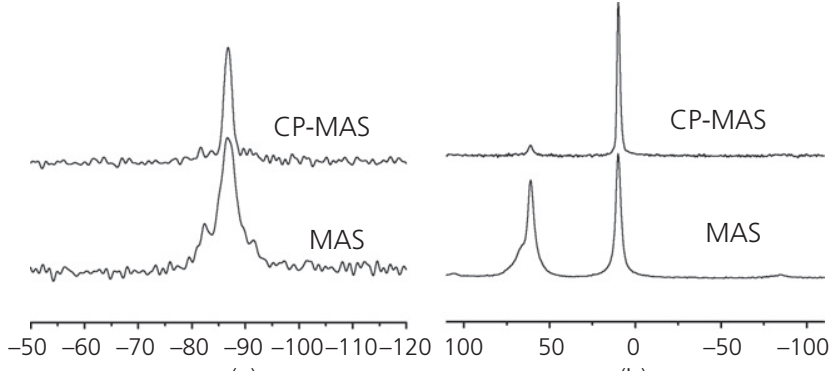

(a)

(b)

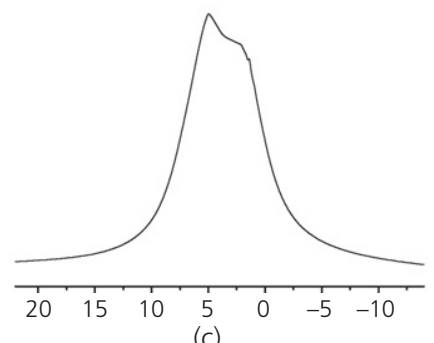

Figure 4. ${ }^{29} \mathrm{Si},{ }^{27} \mathrm{Al}$ and ${ }^{1} \mathrm{H}$ NMR (MAS and CP-MAS) spectra ( $\mathrm{a}, \mathrm{b}$ and $c$, respectively) for laboratory-synthesised stratlingite powder

two small bands located at -82 and $-91 \mathrm{ppm}$, assigned to $\mathrm{Q}_{2}(2 \mathrm{Al})$ and $\mathrm{Q}_{3}(2 \mathrm{Al})$, respectively. The absence of these bands in CP-MAS spectra may be related to the lower condensation (fewer $\mathrm{OH}$ groups). Hence, $\mathrm{Q}_{2}$ is the most probable structure, which may well be assigned to open chains $\left(\mathrm{Q}_{1}\right.$ and $\left.\mathrm{Q}_{2}\right)$ or to closed six-membered rings $\left(\mathrm{Q}_{2}\right)$. However, the existence of square rings may justify the presence of an ordered alternation of $\mathrm{Si}-\mathrm{Al}-\mathrm{Si}-\mathrm{Al}$ within them. This fact would justify the assignation of the signal at $-82 \mathrm{ppm}$ to $\mathrm{Q}_{2}(2 \mathrm{Al})$. Kwan et al. (1995) also observed a band at $\sim-90 \mathrm{ppm}$ in the ${ }^{29} \mathrm{Si}$ CP-MAS-NMR spectra of stratlingite without extra alkali. This is attributed to complex $\mathrm{Q}_{2}$ silicate species within ring structures. On the other hand, $\mathrm{Q}_{2}(2 \mathrm{Al}), \mathrm{Q}_{2}(1 \mathrm{Al})$ chains may exist between AFm consecutive layers. The condensation of parallel chains, based on the condensation of $\mathrm{Si}-\mathrm{OH}$ groups of consecutive chains, may favour the formation of rings with four elements $(\mathrm{Si}-\mathrm{Al}-\mathrm{Si}-\mathrm{Al}$ associations in $\mathrm{Q}_{2}(2 \mathrm{Al})$ areas).

${ }^{27} \mathrm{Al}$ MAS NMR spectrum (Figure 4(b)) shows two bands; the first one centred at $\sim 61 \mathrm{ppm}$, ascribed to tetrahedral Al with a shoulder at $\sim 68 \mathrm{ppm}$ related with lower condensed tetrahedral $\mathrm{Al}$, and the second one located at $9.9 \mathrm{ppm}$, with higher intensity, which is related to the octahedral aluminium. Relative amounts of octa- and tetrahedral aluminium agree with the formula deduced by SEM-EDS analysis. Additionally, ${ }^{1} \mathrm{H}$ NMR spectrum shows two bands, Figure 4(c), one ascribed to water (5 ppm) and another one (at $2 \mathrm{ppm}$ ) assigned to Al-OH or $\mathrm{Si}-\mathrm{OH}$ groups.

Finally, in this model, silicon substituted by aluminium tetrahedral layers cannot exist without any cation compensating 
charge. Because of that, links between the two types of layers should exist: that is, $\mathrm{Al}_{\text {tet }}-\mathrm{O}-\mathrm{Ca}$ and $\mathrm{Al}_{\text {tet }}-\mathrm{O}-\mathrm{Al}_{\text {oct }}$. The existence of these links would justify the union between adjacent octahedral and tetrahedral layers, and would explain the lack of ${ }^{1} \mathrm{H}-^{27} \mathrm{Al}$ polarisation transference in CP-MAS experiments (absence of some peaks in ${ }^{27} \mathrm{Al} \mathrm{CP}-\mathrm{MAS}$ spectra). In this model, the detected partial occupations in the tetrahedral layers should not be considered as defects but as unfinished

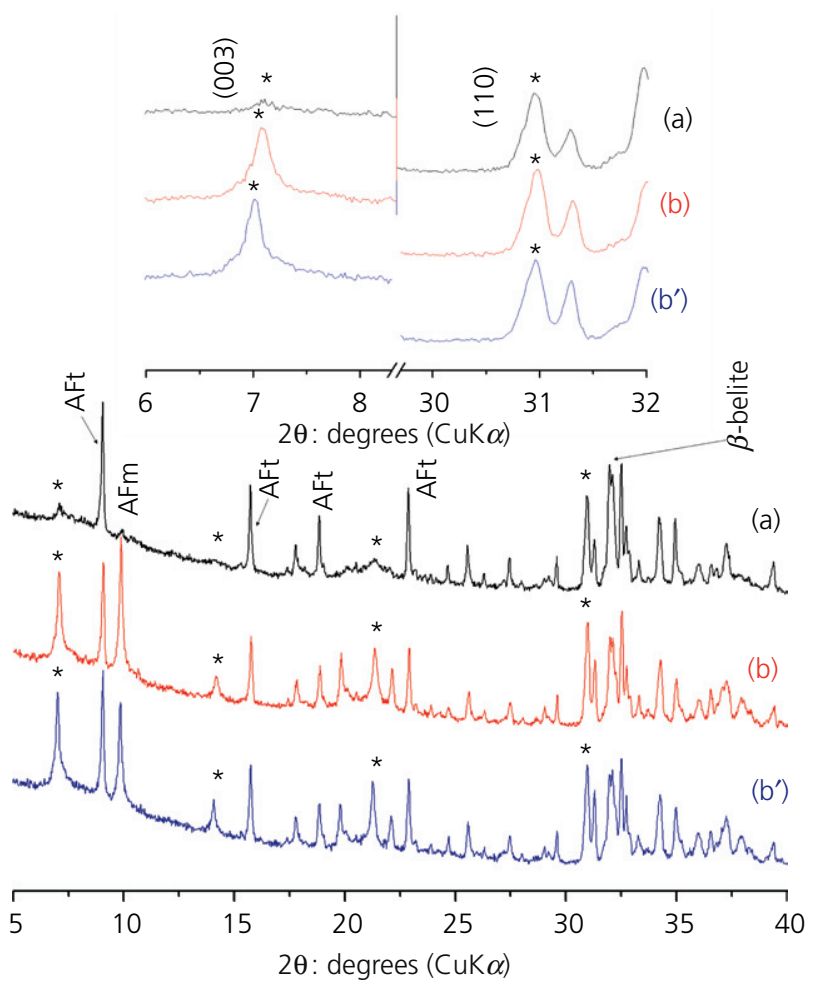

Figure 5. Raw LXRPD patterns of BCSA pastes prepared following methodologies (a) sample holder + stopped hydration, (b) cylinder + stopped hydration and $\left(b^{\prime}\right)$ cylinder non-stopped hydration methodologies. Main stratlingite peaks are marked with an asterisk. The insets show an enlarged range where (003) and (110) lines are located tetrahedral layers. This would justify the existence of interactions between well-defined adjacent layers, and the existence of stratlingite with different spectra.

\section{Stratlingite in cement pastes}

Figure 5 shows raw LXRPD patterns of BCSA pastes prepared following (a), (b) and ( $\left.b^{\prime}\right)$ methodologies, detailed in the experimental section. These samples contain, as main phases, anhydrous $\beta$-belite and ettringite (AFt), a sulfate-bearing AFm type phase (AFm) and stratlingite as hydration products. The main peaks of the latter are marked with an asterisk. The inset gives an enlarged angular range of the patterns, where (003) line, $\sim 7^{\circ}(2 \theta \mathrm{CuK} \alpha)$, and $(110)$ line, $\sim 31^{\circ}(2 \theta \mathrm{CuK} \alpha)$, of stratlingite are shown in detail. Table 3 shows the FWHM values of these two lines and the unit cell parameters of stratlingite in all the BCSA paste patterns. On the one hand, the (003) line position is slightly shifted to higher angles, that is, lower interlaminar space and volume, when BCSA pastes are measured after stopping hydration. This is an indicator of some kind of stratlingite dry damaging (Zhang and Glasser, 2000), probably a joint effect of dehydration and disorder. This effect is obviously not observed in (110) line as it is not related to the inter-laminar space. The (003) line displacement is larger for the paste prepared by methodology (a), which is related to higher dehydration effects. This phenomenon may be expected, as this paste was not stored under water and also, had a high surface in contact with air. On the other hand, pastes with a higher degree of dehydration effect, that is methodology (a), show larger disorder between their layers, provoking an enlargement of FWHM value of (003) line, see Table 3. However, those lines, for instance (110), related to the brucitetype layer are not influenced by this effect. Moreover, the formation of the sulfate-bearing AFm type phase is also affected by the curing methodology. Methodology (a) results as the less favourable one, as that phase almost did not crystallise in the sample. Table 4 shows refined profile parameters to fit stratlingite which is present in LXRPD patterns of BCSA pastes prepared by the three methodologies previously detailed. The stratlingite peak shape was fitted by a pseudo-Voigt function with both isotropic Gaussian, GW, and anisotropic Lorentzian, LY, STEC and PTEC contributions (Thompson

\begin{tabular}{|c|c|c|c|c|c|c|c|}
\hline \multirow[b]{2}{*}{ Methodology } & \multicolumn{2}{|c|}{ (003) line } & \multicolumn{2}{|c|}{ (110) line } & \multicolumn{3}{|c|}{ Cell parameters } \\
\hline & $2 \theta:$ degrees & FWHM: degrees & 20: degrees & FWHM: degrees & $a: \mathrm{nm}$ & C: $\mathrm{nm}$ & $V\left(\mathrm{~nm}^{3}\right)$ \\
\hline a & $7 \cdot 11(1)$ & $0 \cdot 25(4)$ & $30 \cdot 94(1)$ & $0 \cdot 20(1)$ & $0 \cdot 57704(4)$ & $3 \cdot 724(2)$ & $1 \cdot 0738(6)$ \\
\hline b & $7 \cdot 09(1)$ & $0 \cdot 22(1)$ & $30 \cdot 96(1)$ & $0 \cdot 20(1)$ & $0 \cdot 57705(5)$ & $3 \cdot 7290(7)$ & $1.0754(3)$ \\
\hline$b^{\prime}$ & $7 \cdot 01(1)$ & $0 \cdot 18(1)$ & $30 \cdot 94(1)$ & $0 \cdot 20(1)$ & $0 \cdot 57681(5)$ & $3 \cdot 7458(7)$ & $1.0793(2)$ \\
\hline
\end{tabular}

Table 3. FWHM values for (003) and (110) lines (20 CuK $\alpha$ ), and cell parameters of stratlingite in all the BCSA paste patterns prepared by (a) sample holder+stopped hydration, (b) cylinder + stopped hydration and $\left(b^{\prime}\right)$ cylinder non-stopped hydration methodologies 


\begin{tabular}{|c|c|c|c|c|c|c|}
\hline Methodology & $\begin{array}{c}\text { Gaussian } \\
\text { GW: degrees }\end{array}$ & $\begin{array}{l}\text { Lorentzian } \\
\text { LY: degrees }\end{array}$ & $\begin{array}{l}\text { STEC }{ }^{a} \text { : } \\
\text { degrees }\end{array}$ & $\begin{array}{l}\text { PTEC }{ }^{\mathrm{a}} \text { : } \\
\text { degrees }\end{array}$ & $\begin{array}{c}\text { Stratlingite (anisotropic } \\
\text { peak shape): wt\% }\end{array}$ & $\begin{array}{l}\text { Stratlingite (isotropic } \\
\text { peak shape): wt } \%\end{array}$ \\
\hline a & $0 \cdot 64(7)$ & $0 \cdot 22(3)$ & $0 \cdot 34(-)$ & $0 \cdot 80(-)$ & $31 \cdot 2(5)$ & $11 \cdot 4(4)$ \\
\hline$b$ & $0 \cdot 34(6)$ & $0 \cdot 40(3)$ & $0 \cdot 34(-)$ & $0 \cdot 20(1)$ & $30 \cdot 6(5)$ & $22 \cdot 5(3)$ \\
\hline$b^{\prime}$ & $0 \cdot 33(5)$ & $0 \cdot 35(3)$ & $0 \cdot 34(-)$ & $0 \cdot 144(9)$ & $28 \cdot 0(5)$ & $21 \cdot 9(3)$ \\
\hline
\end{tabular}

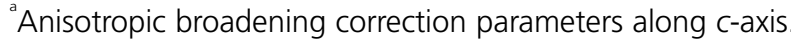

Table 4. Refined anisotropic profile parameters to fit stratlingite and weight percentage of this phase obtained by RQPA of all the BCSA paste patterns prepared by (a) (sample holder + stopped hydration), (b) (cylinder + stopped hydration) and (b') (cylinder non-stopped hydration) methodologies

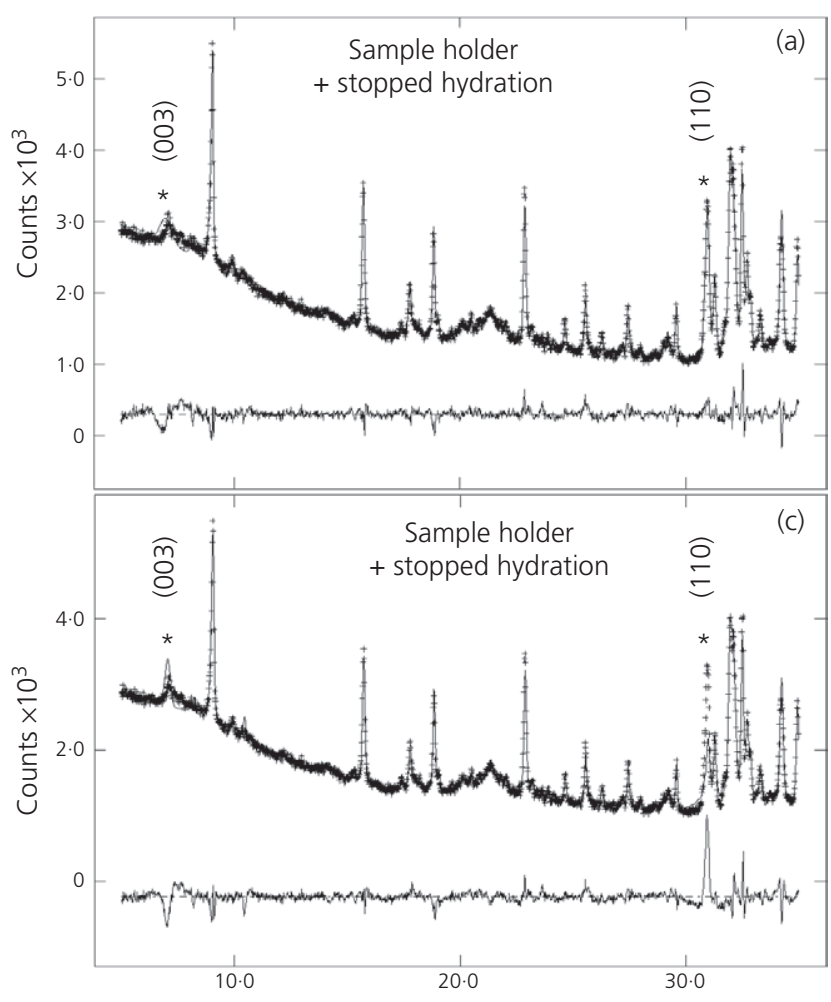

$2 \theta$ : degrees $(\lambda=0.15406 \mathrm{~nm})$

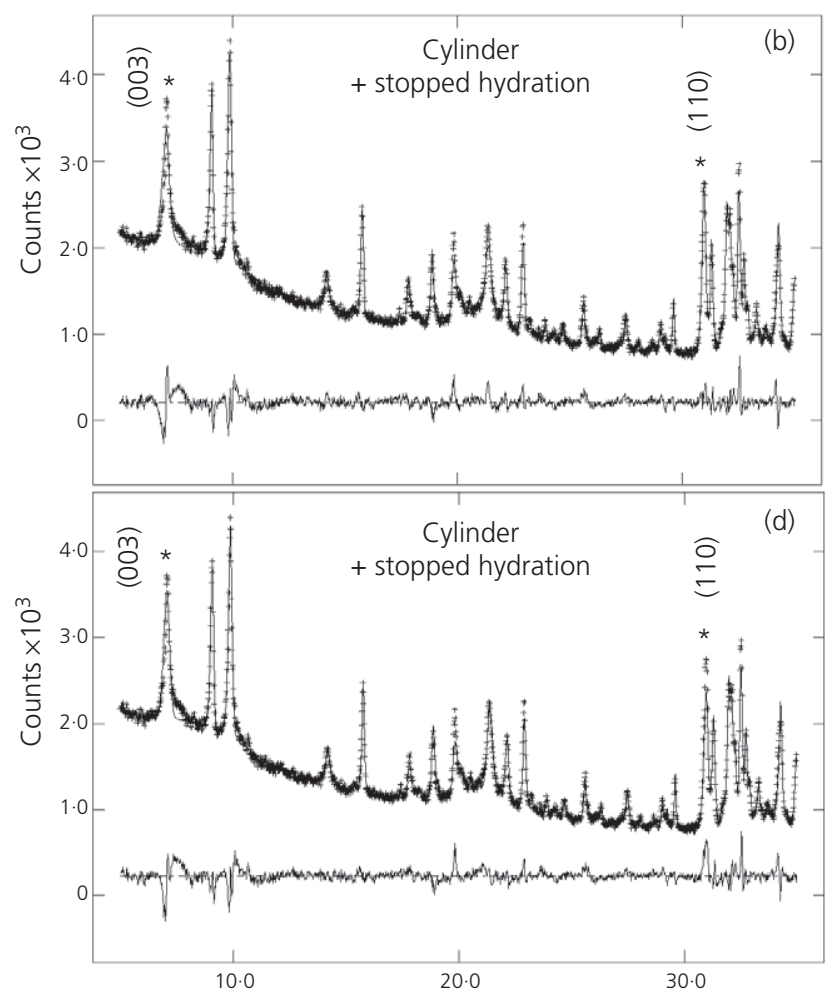

$2 \theta$ : degrees $(\lambda=0 \cdot 15406 \mathrm{~nm})$

Figure 6. Rietveld plots for LXRPD patterns of BCSA pastes prepared by different methodologies, (a) and (b) with the anisotropic broadening correction to fit stratlingite phase and (c) and (d) without modelling the microstructure

et al., 1987). The two last parameters define the anisotropic broadening along the $c$-axis. The modelling of the microstructure of stratlingite is important to derive suitable RQPA results for pastes containing this phase. Figures 6(a) and 6(c) show Rietveld plots of BCSA pastes prepared following (a) and (b) methodologies, respectively, where the anisotropic broadening correction has been applied along the $c$-axis. In addition, Figures 6(b) and 6(d) show the Rietveld fits by using an isotropic pseudo-Voigt function. The fit of (110) line shows a greater mismatch when the microstructure of stratlingite is not modelled. This effect has been especially dramatic in the case of methodology (a) where the paste suffered dry damaging, Figure 6(b). Moreover, Table 4 includes the weight percentages of stratlingite in all pastes obtained by RQPA modelling the microstructure and without any anisotropic contribution. It has to be noted that the three pastes have been prepared 
with the same cement, w/c ratio and at the same time of hydration by using different hydration methodologies. Consequently, phase assemblage should be almost identical. When the microstructure of stratlingite is not modelled, the obtained percentages of stratlingite present a great mismatch (see Table 4), being larger for the sample prepared following methodology (a)

\section{Conclusions}

Crystalline stratlingite has been prepared as a bulk powder sample. Its AFm-type structure can be described as alternating tetrahedral and octahedral layers. The octahedral layer (brucitetype) is formed by $\left[\mathrm{Ca}_{2} \mathrm{Al}(\mathrm{OH})_{6}\left(\mathrm{H}_{2} \mathrm{O}\right)_{2}\right]^{+}$units and the tetrahedral double layer can be described as $\left[\mathrm{Si}_{1 \cdot 24} \mathrm{Al}_{0 \cdot 76} \square_{2} \mathrm{O}_{2}(\mathrm{OH})_{4 \cdot 242}\right.$ $\left.\left(\mathrm{H}_{2} \mathrm{O}\right)_{0 \cdot 25}\right]^{-}$. The structure and microstructure of stratlingite have been studied by synchrotron X-ray powder diffraction data. Its powder pattern displays strong anisotropic peak broadening with quite broad (00 1) diffraction peaks. Conversely, the (hk0) diffraction peaks are relatively much sharper. This microstructure has been successfully modelled with the available anisotropic peak shape function available in the GSAS package. The refinement of the structure includes atomic positions and isotropic atomic displacement parameters (ADPs) with constraints in the oxygenbearing species to yield to a physically realistic description. Acceptable values of $R_{\mathrm{WP}}$ and $R_{\mathrm{F}}$ values were obtained: $6 \cdot 3$ and $7 \cdot 5 \%$, respectively.

${ }^{29} \mathrm{Si}$ MAS NMR spectra indicate that $\mathrm{Q}_{2}$ is the most probable structure, which may well be assigned to open chains $\left(\mathrm{Q}_{1}\right.$ and $\left.\mathrm{Q}_{2}\right)$ or to closed six-membered rings $\left(\mathrm{Q}_{2}\right)$ for the double tetrahedral layer. ${ }^{27} \mathrm{Al}$ MAS NMR spectra show a band ascribed to tetrahedral aluminium with a shoulder related to a lower condensed tetrahedral aluminium, and another one with higher intensity is related to the octahedral aluminium.

The stratlingite phase formed in cement pastes is sensitive to the hydration conditions. When BCSA pastes after stopping hydration are characterised through LXRPD, the (003) line position appears slightly shifted to higher angles (lower interlaminar space and volume) compared with the similar paste but without stopping hydration. This is likely related to dehydration and disorder. This shift is even larger when the paste has suffered some dehydration during curing (apart from stopping hydration); in that case, stratlingite shows a larger disorder between its layers, provoking an enlargement of the FWHM value of (001) lines. Modelling the microstructure of stratlingite is important to derive suitable RQPA results in BCSA pastes containing this phase. This is especially relevant for pastes that suffered dry damaging.

\section{Acknowledgements}

This work has been supported by Junta de Andalucía through P11-FQM-07517 research project. I. Santacruz offers thanks for a Ramón y Cajal fellowship, RYC-2008-03523. Synchrotron experiments were performed in the MSPD (Materials
Science and Powder Diffraction) beamline at Alba Synchrotron Light Facility with the collaboration of François Fauth.

\section{REFERENCES}

Álvarez-Pinazo G, Cuesta A, García-Maté M et al. (2012)

Rietveld quantitative phase analysis of yeelimitecontaining cements. Cement and Concrete Research 42(7): 960-971.

Álvarez-Pinazo G, Santacruz I, León-Reina L et al. (2013) Hydration reactions and mechanical strength developments of iron-rich sulfobelite eco-cements. Industrial and Engineering Chemistry Research 52(47): 16606-16614.

Aranda MAG, De la Torre AG and León-Reina L (2012) Rietveld quantitative phase analysis of OPC clinkers, cement and hydration products. Review in Mineralogy and Geochemistry 74(1): 169-209.

Balonis M and Glasser FP (2009) The density of cement phases. Cement and Concrete Research 39(9): 733-739.

Cuberos AJ, De la Torre AG, Alvarez-Pinazo G et al. (2010) Active iron-rich belite sulfoaluminate cements: clinkering and hydration. Environmental Science and Technology 44(17): 6855-6862.

Cuesta A, Losilla ER, Aranda MAG et al. (2012) Reactive belite stabilization mechanisms by boron-bearing dopants. Cement and Concrete Research 42(4): 598-606.

Cuesta A, de la Torre AG, Losilla ER et al. (2013) Structure, atomistic simulations, and phase transition of stoichiometric yeelimite. Chemistry of Materials 25(9): 1680-1687.

Cuesta A, Aranda MAG, Sanz J et al. (2014) Mechanism of stabilization of dicalcium silicate solid solution with aluminium. Dalton Transactions 43(5): 2176-2182.

De la Torre AG, Bruque S, Campo J et al. (2002) The superstructure of $\mathrm{C}_{3} \mathrm{~S}$ from synchrotron and neutron powder diffraction and its role in quantitative phase analyses. Cement and Concrete Research 32(9): 1347-1356.

Dilnesa BZ, Lothenbach B, Renaudin G et al. (2014) Synthesis and characterization of hydrogarnet $\mathrm{Ca}_{3}\left(\mathrm{Al}_{\mathrm{x}} \mathrm{Fe}_{1-\mathrm{x}}\right) 2\left(\mathrm{SiO}_{4}\right)$ $\mathrm{y}(\mathrm{OH})$ 4(3-y). Cement and Concrete Research 59: 96-111.

Fauth F, Peral I, Popescu C et al. (2013) The new material science powder diffraction beamline at ALBA synchrotron. Powder Diffraction 28(S2): S360-S370.

Fleischer M and Jambor J (1977) New mineral names. American Mineralogist 62: 395-397.

García-Maté M, De la Torre AG, León-Reina L et al. (2013) Hydration studies of calcium sulfoaluminate cements blended with fly ash. Cement and Concrete Research 54: $12-20$.

Gartner E and Li GS (2006) High Belite-Containing Sulfoaluminous Clinker, Method for the Production and the Use thereof for Preparing Hydraulic Binders. World Patent Application WO2006/018569 A2. 
Gartner EM (2004) Industrially interesting approaches to 'low- $\mathrm{CO}_{2}$ ' cements. Cement and Concrete Research 34(9): 1489-1498.

Hentschel GV and Kuzel HJ (1976) Stratlingite, $2 \mathrm{CaO} \cdot \mathrm{A}_{2} \mathrm{O}_{3} \cdot \mathrm{SiO}_{2} \cdot 8 \mathrm{H}_{2} \mathrm{O}$, ein Neues Mineral. Neues Jahrb Mineral Monatsh 319-325.

Klaus SR, Neubauer J and Goetz-Neunhoeffer F (2013) Hydration kinetics of $\mathrm{CA}_{2}$ and $\mathrm{CA}$ - investigations performed on a synthetic calcium aluminate cement. Cement and Concrete Research 43: 62-69.

Kuzel HJ (1976) Crystallographic data and thermal decomposition of synthetic gehlenite hydrate $2 \mathrm{CaO} \times \mathrm{Al}_{2} \mathrm{O}_{3} \times \mathrm{SiO}_{2} \times 8 \mathrm{H}_{2} \mathrm{O}$. Neues Jahrbuch fuer Mineralogie Monatshefte 148: 319-325.

Kwan S, Larosa J and Grutzeck MW (1995) 29Si and 27Al MASNMR study of stratlingite. Journal of the American Ceramic Society 78(7): 1921-1926.

Larson AC and Von Dreele RB (2000) General Structure Analysis System (GSAS). Los Alamos National Laboratory Report LAUR, Los Alamos, NM, USA, pp. 86-748.

Le Saoût G, Lothenbach B, Hori A, Higuchi T and Winnefeld F (2013) Hydration of Portland cement with additions of calcium sulfoaluminates. Cement and Concrete Research 43: 81-94.

Marchi M and Costa U (2011) Influence of the calcium sulphate and w/c ratio on the hydration of calcium sulphoaluminate cement. Proceedings of 13th International Congress on the Chemistry of Cement, Madrid, Spain.

Matschei T, Lothenbach B and Glasser FP (2007a) Thermodynamic properties of Portland cement hydrates in the system $\mathrm{CaO}-\mathrm{Al}_{2} \mathrm{O}_{3}-\mathrm{SiO}_{2}-\mathrm{CaSO}_{4}-\mathrm{CaCO}_{3}-\mathrm{H}_{2} \mathrm{O}$. Cement and Concrete Research 37(10): 1379-1410.

Matschei T, Lothenbach B and Glasser FP (2007b) The AFm phase in Portland cement. Cement and Concrete Research 37(2): 118-130.
McCaffrey R (2002) Climate change and the cement industry. Global Cement and Lime Magazine. Environmental Special Issue 15-19.

Moon JH, Oh JE, Balonis M et al. (2011) Pressure induced reactions amongst calcium aluminate hydrate phases. Cement and Concrete Research 41(6): 571-578.

Morin V, Gartner EM, Walenta G et al. (2011) Hydration of a belite-calcium sulfoaluminate-ferrite cement: AetherTM. Proceedings of 13th International Congress on the Chemistry of Cement, Madrid, Spain.

Passaglia E and Turconi B (1982) Silicati ed Altri Minerali di Montalto di Castro-VT. Rivista Mineralogica Italiana 4: 97-110.

Rinaldi R, Sacerdoti M and Passaglia E (1990) Stratlingite: crystal structure, chemistry, and a reexamination of its polytype vertumnite. European Journal of Mineralogy 2(6): 841-849.

Sahu S, Havlica J, Tomková V et al. (1991) Hydration behaviour of sulphoaluminate belite cement in the presence of various calcium sulphates. Thermochimica Acta 175(1): $45-52$.

Taylor HFW (1997) Cement Chemistry. Thomas Telford, London, UK.

Thompson P, Cox DE and Hasting JB (1987) Rietveld refinement of Debye-Scherrer synchrotron X-ray data from $\mathrm{Al}_{2} \mathrm{O}_{3}$. Journal of Applied Crystallography 20(2): 79-83.

Wang J (2010) Hydration Mechanism of Cements based on Low-CO $\mathrm{C}_{2}$ Clinkers Containing Belite, Ye'elimite and Calcium Alumino-ferrite. PhD thesis, University of Lille, Lille, France.

Winnefeld F and Lothenbach B (2010) Hydration of calcium sulfoaluminate cements-experimental findings and thermodynamic modeling. Cement and Concrete Research 40(8): 1239-1247.

Zhang L and Glasser FP (2000) Critical examination of drying damage to cement pastes. Advances in Cement Research 12(2): 79-88, http://dx.doi.org/10.1680/adcr.2000.12.2.79.

\section{WHAT DO YOU THINK?}

To discuss this paper, please submit up to 500 words to the editor at journals@ice.org.uk. Your contribution will be forwarded to the author(s) for a reply and, if considered appropriate by the editorial panel, will be published as a discussion in a future issue of the journal. 